\title{
Screening of essential oils activity against a gram negative psychrophilic bacterium isolated from aquatic environment (Water \& Biofilm)
}

\author{
Assia. Kritihi ${ }^{1,2, *}$ Khadija Ouaissa ${ }^{1}$, Abdelaziz Maychal ${ }^{2}$, Younes Oumessaoud ${ }^{2}$ and Mustapha Hasnaoui ${ }^{1}$ \\ ${ }^{1}$ Environmental Engineerig Team, Faculty of Sciences and Techniques, Sultan Moulay Slimane University. BO. 523. M'Ghila, 23000 \\ Beni Mellal. Morocco. \\ ${ }^{2}$ Ain Aghbal pisciculture Farm, Azrou.
}

\begin{abstract}
Among the applications of medicinal plants, it is their use as antimicrobial agents. The objective of this study was to investigate the effect of some essential oils against an etiological pathogen Flavobacterium spp. responsible for several lost in rainbow trout, (Oncorhynchus mykiss) hatcheries, the strains used in this study were isolated from rearing tanks water and biofilm, identified as Flavobacterium spp. based on phenotypic, biochemical and enzymatic characterizations. A collection of eight essential oils were extracted, analyzed and tested for an inhibitory activity against the isolated strains, the effect on this bacterium has been demonstrated by the aromatogram method based on a screening of bacterial growth in a solid medium culture with disks containing essential oils. Our study's results show that the chemical composition of the extracted essential oils play a crucial role in their antibacterial activity, which varies from $6 \mathrm{~mm}$ up to $34 \mathrm{~mm}$ as maximal inhibitory diameter.
\end{abstract}

\section{Introduction}

A bacterial isolate from rearing tank water and biofilm in a fish farm in Morocco, was characterized for its physiological, enzymatic and biochemical features as Flavobacterium spp, in comparison with seven strains of Flavobacterium psychrophilum.

In general, Flavobacteria are aerobic nonfermentative bacteria, catalase and oxidase positive, gram negative, yellow rods frequently isolated from different ecosystems, and it is considered to be a bacterial group of special relevance for aquatic environments (marine and freshwater). The importance of Flavobacterium spp. as a fish pathogen and the increasing significance of the disease are given by the huge number of economic lost known in the salmonid hatcheries world wild, especially in early ages. Currently there is no vaccine and the only treatment existing is the antibiotic therapy. Antibiotics become more and more complex and chemically synthesized but despite that the new generations may not be able to inhibit and/or control the development, and growth of pathogenic microorganisms, due to their capacity of transmitting genetic material and acquiring new resistances against the active molecules of these antibiotics.

Nowadays, antibiotics residues are reported to be ineffective in controlling diseases in aquaculture due to the misuse or overuse of antibiotics by fish farmers. Furthermore, antibiotics residues are found as a threat to human health [1] and the environment [2].
This situation leads to the recurring public health problems related to bacterial resistance to antibiotics, this leads to think about new natural treatments which means a return to the traditional medicine, and more specifically the herbal medicine, on the basis of essential oils extracted from aromatic and medicinal plants; theses essential oils are a part of secondary metabolites, which the plant produces in some conditions for the majority of cases to protect themselves against pests.

These essential oils have several uses, they can be used in medicine, and power supplies are for aromatization or conservation, also in cosmetic [3]. The antimicrobial properties of essential oils have been described [4], as natural products from the aromatic and medicinal plants, they are known by their antiviral, antibacterial, antifungal and antioxidant power [5-6]. Currently there is interest in herbal medicine as an alternative of synthesized antibiotics [7].

Many studies have been made to reveal the antibacterial power of essential oils either on the bacteria Gram-positive or negative, which justifies the research that been made in traditional medicine for the characterization of this power, the more it is admitted that the essential oils can be active even on the multi resistant pathogenic microorganisms [8]. The plants and their components are sources potentially rich in antimicrobial substances. Many studies have been published confirming the presence of this activity against different types of microorganisms, [9-10-11].

*orresponding author: $\underline{\text { assiakritihi@gmail.com }}$ 


\section{Material and Methods}

\subsection{Biological material}

Water samples were collected from the rearing tanks in the fish farm, sampled during the four seasons in 2015. Water samples were collected from each tank using acidrinsed and autoclaved polycarbonate bottles. Water samples were kept dark at $4^{\circ} \mathrm{C}$ before analysis.

Biofilm samples were taken in the same time and in aseptic conditions, from the same fish rearing tanks and transported in sterile sampling pots under controlled conditions.

Processed samples were plated onto TYES agar. Plates were incubated at $16^{\circ} \mathrm{C}$ for 7 to $10 \mathrm{~d}$ and bacterial growth was recorded. Yellow pigmented flat or very thin colonies, spreading, with uneven, rhizoid, or filamentous margins were selected and sub-cultured for phenotypic, enzymatic and biochemical analysis.

To be identified as Flavobacterium spp. the isolates were tested for a number of key characteristics using standard procedures [12], such as cell size and morphology (phase-contrast microscopy), Gram stain, congo red absorption, $\mathrm{KOH}$ string test, cytochrome oxidase and catalase $(3 \%$ H2O 2$)$. Furthermore, production of indole, growth on enriched medium with $0.5-1.5 \% \mathrm{NaCl}$, nitrate reduction, and hydrolysis of casein, tyrosine, starch, gelatin, chitinase, cellulase and pectinase activities were tested as described by [13]. The strains were also characterized by using the whole test spectrum of the identification systems API 20E and API $20 \mathrm{NE}$ at $16^{\circ} \mathrm{C}$. The gleeding motility was tested using the hanging drop method.

\subsection{Vegetal material}

The essential oils (EO) are not simple bodies, but in general, they are assemblies of molecules each once have her specific properties. The importance of the knowledge of families, botanical genera and species is obvious, and also their provenance. The plants witch they are botanically identic can, indeed, give some essences whose the differences are more or less important.

The true lavender (lavandula vera or angustifolia or officinalis) is part of the Labiatae. It grows in Mediterranean Europe, on limestone land, $700 \mathrm{~m}$ up to 1 $800 \mathrm{~m}$ of altitude. Its leaves are long, narrow and whitish; the whole plant has aromatic smell very pleasant [14].

Sage (Salvia officinalis, Labiatae) was seen among our ancestors (the Gauls), as well as among all the other peoples of Antiquity, as the plant salutary by excellence, so wonderful that they considered all able to cure all diseases [15].

The wild chamomile, Cladanthus mixtus, also called Chamomile commercially of Morocco, is an Asteracea biennial chamephyte to numerous erect stems, this species is characterized by a fresh smell balsamic. It gives an essential oil of camphre smell sought in cosmetic, perfumery and Medicine [16].
Cloves (which is a male name, contrary to the current use) or gerofle or clove, is the floral button of a tree originating in the Moluccas Islands, which are the homeland of giroflier (Eugenia caryophyllata, or caryophyllus, Myrtaceae) [17].

The geranium the Pelargonium graveolens (family Geraniaceae), belongs to the category of perennial plants to fragrant foliage. Evergreen leaves are lobed and opposite, covered with glandular hairs microscopic organisms that release their scents to the touch or to the heat [18]. The plant is cultivated in many Mediterranean regions and subtropics [19].

Rosemary, rosmarinus officinalis Labiaceae, common plant in the wild, is, without doubt, one of the plants the most popular in Morocco This plant belongs to the family of Labiatae. It presents itself in the form of shrub, under shrub or herbaceous. The leaves are narrowly lanceolate linear, brittle and tough, the flowers of a pale blue, stained inwardly from the purple are arranged in short dense clusters thrive almost throughout the year [20].

The eucalyptus (Eucalyptus globulus - Myrtaceae) is originating in Australia and Tasmania and it is cultivated in some subtropical regions of the South of Europe, Africa, Asia, and America. The oil of Eucalyptus is obtained from the leaves of the plant [21-22].

The hydrodistillation of the wood of cedars (Cedrus atlantica), a bio-test performed with the essential oil gross and its fractions showed an antimicrobial activity observed predominantly in the fractions rich in terpenols. [23].

The harvested plants were manipulated carefully and all the essential oils tested have been extracted by steam drive of water using an experimental setup within « Les Aromes du Maroc » Domain -Tiddas, except the essential oil of Lavandula angustifolia that comes from a traditional distillery in Ben Smim-Azrou; and the essential oil of the Cedrus atlantica which comes from the society "Cèdre de l'Atlas-Azrou ». The chemical analysis of essential oils has been carried out by CPG$\mathrm{MS}$, in the laboratory of physico-chemical analysis in « Les Aromes du Maroc » Domain -Tiddas.

\subsection{Aromatogram}

The Purpose of the Aromatogram is to determinate (in vitro) which Essential Oils are to be considered as active or inactive against a bacterium. The choice of using certain Essential Oils will be determined by various criteria gathered from the Aromatogram - same as in the case of an Antibiogram.

The designation of an Essential Oil by the Aromatogram is an indication of its antibacterial properties in vitro against a considered germ. So it is a method which allows determining the inhibitory activity of essential oils, if it exists by the measurement of the diameter of inhibition around a disk of cellulose impregnated with essential oil.

It is a qualitative method which makes it possible to study on a solid culture medium the action of an agent antibacterial, and to give indications on its effectiveness 
in vitro. The antibacterial activity of essential oils was determined separately, using the disc diffusion method [24].

A suspension of each strain is prepared in physiological water and adjusted to $10^{8}$ bacteria $/ \mathrm{ml}$. Each suspension $(100 \mu \mathrm{l})$ is spread on a Petri dish of 90 $\mathrm{mm}$ diameter. The surface of the Petri dishes is dried under the hood laminar flow with slightly opened cover of the Petri dishes.

The sterile paper disks blotting of $6 \mathrm{~mm}$ in diameter are impregnated with essential oil and then tests were made three times. The reading of the inhibition diameters was done after 7 to 10 days of incubation in the oven at $15{ }^{\circ} \mathrm{C}$. The results are expressed according to three levels of activity: resistant $(\mathrm{d}<6 \mathrm{~mm})$, intermediate $(13 \mathrm{~mm}<\mathrm{d}>6 \mathrm{~mm})$ and sensitive $(\mathrm{D}>13$ $\mathrm{mm})$.

\section{Results and Discussion}

The identification of bacteria is respecting the classical protocols, the morphological and phenotypic characteristics of all the bacterial strains examined were in agreement with those described in previous published reports, and they are yellow pigmented colonies, gram negative bacillus and adopting a movement by gleeding [25]. However, our strains present a homogeny enzymatic pattern.

Despite, the biochemical analysis show that the studied strains are all Congo red absorbent, CIT positive, Indole negative, they grow up in a medium supplemented with $1 \%$ of $\mathrm{NaCl}$ and they can't degrade glucans. But they respond differently on some tests; the found results are illustrated in the table (1).

Table 1. Biochemical characterization of the studied strains

\begin{tabular}{|l|l|l|l|l|l|l|l|}
\hline \multirow{2}{*}{$\begin{array}{l}\text { Bacterial } \\
\text { strains }\end{array}$} & \multicolumn{6}{|l|}{ Biochemical tests } \\
\cline { 2 - 7 } & ONPG & ADH & LDC & ODC & $\mathrm{H}_{2}$ S & URE & F.P.T \\
\hline 404 & N & N & N & N & N & N & P \\
\hline 405 & P & N & N & N & N & N & N \\
\hline 406 & P & N & P & P & N & N & N \\
\hline 409 & N & N & N & N & N & N & N \\
\hline 901 & N & P & N & N & N & N & N \\
\hline 903 & N & N & N & N & N & N & P \\
\hline 907 & N & N & N & N & N & N & N \\
\hline 911 & N & P & N & N & N & N & N \\
\hline 111 & N & N & N & N & N & N & N \\
\hline 114 & N & N & P & N & N & N & N \\
\hline 117 & N & N & N & N & N & N & P \\
\hline 118 & N & N & N & N & N & N & P \\
\hline 442 & N & N & N & N & N & P & N \\
\hline 445 & P & N & P & N & N & P & N \\
\hline 817 & P & P & P & P & N & P & N \\
\hline 733 & N & N & N & N & N & N & N \\
\hline 738 & P & P & P & P & N & N & N \\
\hline 607 & N & N & N & N & P & N & P \\
\hline 760 & N & N & N & N & P & N & N \\
\hline
\end{tabular}

$\mathrm{N}$ : negative result / P: positive result
The physico-chemical composition of the essential oils is presented in the table (2). To avoid overload in the text, only the compound having content greater than $1 \%$ will be mentioned. The identification is carried out through the comparison of retention times observed on the one hand on samples to characterize, and on the other hand on the heels available.

Table 2. Majority compounds of essential oils used in the study

\begin{tabular}{|c|c|c|c|}
\hline $\begin{array}{l}\text { Essential } \\
\text { oil }\end{array}$ & Majority compounds & Color & Density \\
\hline Lavender & 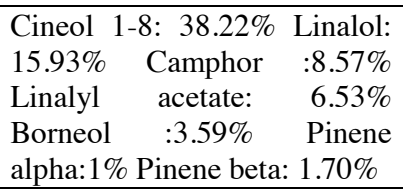 & Pale yellow & 0.933 \\
\hline Sage & $\begin{array}{lrr}\text { Pinene alpha: } & 7,61 \% \\
\text { Camphene: } 4.89 \% & \text { Pinene } \\
\text { beta: } 4.06 \% \text { Myrcene: } & 2.58 \% \\
\text { Limonene cineol 1-8: } & 19.83 \% \\
\text { Thujone alpha: } & 2.75 \% \\
\text { Thujone beta } & 25.51 \% \\
\text { Camphor: } & 10.66 \% & \text { Humulene } \\
\text { alpha: } 4.26 \% & \end{array}$ & $\begin{array}{l}\text { Orange- } \\
\text { yellow }\end{array}$ & 0.779 \\
\hline Chamomile & 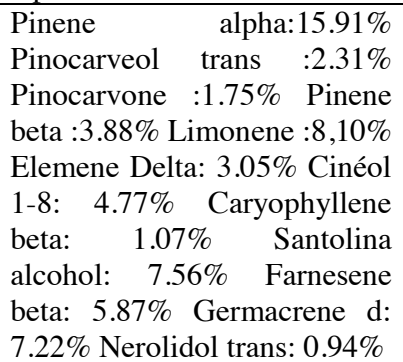 & Pale yellow & 0.952 \\
\hline Clove & $\begin{array}{l}\text { Eugenol: } \quad 85,42 \% \\
\text { Caraphyllène beta: } 9,95 \%\end{array}$ & Pale yellow & 1.040 \\
\hline Geranium & $\begin{array}{lr}\text { Isomenthone: } & 5.55 \% \\
\text { Geraniol: 14.45\% Linalol } \\
: 8.83 \% \text { Citronellyl } & \text { formate } \\
: 5.77 \% \text { Geranyl } & \text { formats: } \\
5.23 \% \text { Citronellol: } & 19.69 \% \\
\text { Butyrate Geranyl: } 2.39 \% 10- \\
\text { epi- gamma-eudesmol: } 9.46 \%\end{array}$ & Pale yellow & 0.873 \\
\hline Rosemary & $\begin{array}{l}\text { Pinene } \\
\text { Camphene: } 3.25 \% \text { Pinene } \\
\text { beta: } 6.63 \% \text { Linalol: } 8.75 \% \\
\text { Myrcene: } 1.63 \% \text { Térpénin-4- } \\
\text { OL: } 2.18 \% \text { Limonene: } 2.15 \% \\
\text { Caryophyllene beta: } 2.34 \% \\
\text { Cinéol 1-8: } 46.12 \% \text { Borneol: } \\
2.88 \% \text { Terpinene gamma: } \\
1.30 \% \text { Verbenone: } 2.15 \%\end{array}$ & Colorless & 0.804 \\
\hline Eucalyptus & $\begin{array}{llr}\text { Cineol 1-8: } 58 \% & \text { Alpha } \\
\text { pinene } & 21,97 \% \text { Limonene: } \\
7.95 \% \text { Paracymene } & : 2.89 \% \\
\text { Globulo } 1.5 \% & \text { Trans } \\
\text { pinocarveol: } & 2.63 \% \\
\text { Aomadendrene: } 1.74 \%\end{array}$ & Colorless & 0.781 \\
\hline Cedar & $\begin{array}{ll}\text { Himachalene alpha: } & 17.35 \% \\
\text { Himachaline beta: } & 46,97 \% \\
\text { Himachaline gamma: } & 12.39 \% \\
\text { Trans Atlantone alpha: } 3.12 \% \\
\text { Cis Atlantone alpha: } 1.46 \% \\
\text { Atlantone beta: } 1.13 \%\end{array}$ & $\begin{array}{c}\text { Pale } \\
\text { yellow- } \\
\text { colorless }\end{array}$ & 0.968 \\
\hline
\end{tabular}


The density tells us about the chemical composition, so a density less than 0.9 indicates the presence of terpene and aliphatic compounds at high rates, while a density greater than 1 indicates a very varied composition of polycyclic terpene compounds [26].

However, the pharmacological properties of essential oils from a few Labiatae, have been demonstrated since 1973 by [27], but in 1974, [28], has described the antibacterial properties of the other essential oils, such as that obtained from the clove and which does not contain phenols but aromatic aldehydes.

The aromatogram realized with strains of Flavobacterium spp. shows that the strains are sensitive to the essential oils of eucalyptus, geranium, lavender, rosemary and the clove, with inhibition diameters up to $35 \mathrm{~mm}$ and they show a resistance to essential oils of cedar, chamomile and sage (Table 3 ).

Table 3. Inhibition diameters of essential oils against Flavobacterium spp. Strains

\begin{tabular}{|c|c|c|c|c|c|c|c|c|}
\hline Strains & $\begin{array}{c}R . \\
\text { offic } \\
\text { inali } \\
s \\
(10 \\
\mu l)\end{array}$ & $\begin{array}{c}S . \\
\text { offici } \\
\text { nalis } \\
(10 \mu \\
l)\end{array}$ & $\begin{array}{c}C . \\
m i \\
x t u \\
s \\
(10 \\
\mu l)\end{array}$ & $\begin{array}{c}\text { L. } \\
\text { angus } \\
\text { tifolia } \\
(10 \mu l)\end{array}$ & $\begin{array}{c}C . \\
\text { atla } \\
\text { ntic } \\
a \\
(10 \\
\mu l)\end{array}$ & $\begin{array}{c}\text { E. } \\
\text { glob } \\
\text { ulus } \\
(10 \\
\mu l)\end{array}$ & $\begin{array}{c}P . \\
\text { grave } \\
\text { olens } \\
(10 \mu l \\
\quad)\end{array}$ & $\begin{array}{c}S . \\
\text { arom } \\
\text { aticu } \\
m \\
(10 \mu l)\end{array}$ \\
\hline 404 & 0.8 & 0.8 & 0.8 & - & 2.0 & 2.8 & 2.0 & 1.2 \\
\hline 405 & - & $\begin{array}{ll}- \\
-\end{array}$ & - & 3.0 & 1.7 & 0.8 & - & 1.8 \\
\hline 406 & - & - & 0.8 & 3.2 & - & - & 1.3 & - \\
\hline 409 & - & - & - & - & - & 1.0 & 1.0 & 1.0 \\
\hline 901 & - & - & - & 1.0 & - & 1.5 & - & 1.8 \\
\hline 苟 903 & 0.8 & - & 1.0 & - & 1.8 & 2.8 & 3.0 & 0.8 \\
\hline 907 & - & - & - & & - & & 1.0 & \\
\hline 911 & - & - & - & - & 1.1 & 1.4 & - & - \\
\hline 111 & & - & - & - & - & & - & - \\
\hline 114 & - & - & - & 2.8 & 1.2 & - & 1.2 & 2.0 \\
\hline 117 & 0.8 & 0.8 & 1.0 & 3.4 & 1.6 & 3.5 & 3.0 & 0.8 \\
\hline 118 & 0.8 & 0.8 & 1.0 & 3.4 & 1.6 & 3.5 & 3.0 & 1.4 \\
\hline 442 & - & - & - & - & - & 3.0 & 1.4 & 1.8 \\
\hline 445 & - & - & 1.1 & - & - & 2.6 & - & 1.6 \\
\hline 817 & - & - & - & - & - & 1.5 & - & - \\
\hline 733 & - & - & 1.0 & - & - & 1.6 & - & - \\
\hline 738 & - & -- & - & - & - & 3.2 & - & - \\
\hline 겨 607 & - & - & 0.8 & - & - & 2.0 & - & - \\
\hline 760 & - & - & - & - & - & 2.4 & - & - \\
\hline
\end{tabular}

E. globulus and L. officinalis come in first position with highest antibacterial activity and inhibition diameters varying between 6 and $30.5 \mathrm{~mm}$ and 6 and $30.4 \mathrm{~mm}$ respectively.

As it has been demonstrated by [27], the essential oil of E. globulus has a powerful antibacterial activity which is in accordance with our finding. As for the tested $L$. officinalis, the antimicrobial activity of this essential oil is mainly due to its richness in the following constituents: Cineol 1-8, camphor, borneol and esters. Indeed, all these compounds are known for their antimicrobial properties, this goes with the results demonstrated in [14].

As for $P$. graveolens and $S$. aromaticum, their essential oils exhibit less activity and inhibition diameters varying between 6 and $30 \mathrm{~mm}$ and 6 and 20 mm respectively.

For the activity of $P$. graveolens essential oil it have been approved by [28], and they propose the use of this natural substance in the pharmaceutical industry for the fight against contamination and biofilms composition. The $S$. aromaticum activity is due principally to eugenol, his major compound which is known by its antibacterial, antifungal and antiviral activities [17].

The essential oils of $C$. atlantica and $C$. mixtus exhibit low activity with inhibition diameters ranging from 6 to $20 \mathrm{~mm}$ and 6 to $11 \mathrm{~mm}$ respectively.

Our essential oil of $C$. mixtus, have a weaken antibacterial activity compared with the results found by [21].

With inhibition diameters not exceeding $8 \mathrm{~mm}$, the essential oils of $R$. officinalis and $S$. officinalis do not exhibit anti-flavobacteric activity. This agrees with the results of [29] who reported that the essential oil of $R$. officinalis from Sardinia has moderate antibacterial activity.

From the found results it can be seen that the reference strains were present more resistance to the oils tested in comparison with our Moroccan isolates, only the essential oil of E. globulus showed a strong activity translated by the diameters of inhibition measured.

Based on the disc diffusion method, this test makes it possible to assess the antibacterial activity of essential oils from the inhibition diameters they generate on a standardized bacterial inoculum. Among the essential oils screened, those with the highest activity were selected to study their mode of action on Flavobacterium spp.

These in vitro experiments have demonstrated effective antimicrobial efficacy of the essential oils of $P$. graveolens, L. officinalis, $E$. globulus and $S$. aromaticum, compared to those of $C$. atlantica and $C$. mixtus except for the essential oil of $S$. officinalis and $R$. officinalis which seem to be ineffective on Flavobacterium spp.

\section{Conclusion}

These results show the importance of making the aromatogram in functions of the targeted germs, as a preliminary step in the selection of essential oils with antibacterial effect and those who do not possess, before starting the second part of the tests which concerns the determination of the CMI (minimum inhibitory concentration), and $\mathrm{CMB}$ (The minimal bactericidal concentration) if the power of essential oils is bactericidal

These first results are encouraging new systematic studies of many essential oils on other samples of pathogenic bacteria with increased resistance against the 
conventional antibiotics. The use of natural products in the place of some synthesis products is also envisaged in the field of animal health because the concept of bio and naturalness is in full progress; we can well imagine the use of theses E.O.

New perspectives can be envisaged by a further study of the antibacterial activity, not only on the E.O used alone, but also in a mixture, thus allowing a possible synergy.

\section{References}

1. Alderman D. J., \& Hastings T. S., 1998 . Antibiotic use in aquaculture: development of antibiotic resistance - potential for consumer health risks*. International Journal of Food Science and Technology, 33(2), 139-155. doi:10.1046/j.13652621.1998.3320139.x.

2. Cabello F. C., 2006. Heavy use of prophylactic antibiotics in aquaculture: a growing problem for human and animal health and for the environment. Environmental Microbiology, 8(7), 11371144. doi:10.1111/j.1462-2920.2006.01054.x.

3. Fabian D., Sabol M., Domaracké K., \& Bujnékovâ D., 2006. Essential oils - their antimicrobial activity against Escherichia coii and effect on intestinal cell viability. Toxicol. in vitro 20, 1435-1445.

4. Pinto E., Pina-Vaz C., Salgueiro L., Gonçalves M.J., Costa-de-Oliveira S., Cavaleiro C., Palmeira A., Rodrigues A. \& Martinez-de-Oliveira J., 2006. Antifungal activity of the essential oil of Thymus pulegioides on Candida, Aspergillus and dermatophyte species. Journal of Medical Microbiology, 55, pp. 1367-1373.

5. Kordali S., Kotan R., \& Mavi A., $2005 a$. Determination of the chemical composition and antioxidant activity of the essential oil of Artemisia dranunculus and of the antifungal and antibacterial activities of Turkish Artemisia absinthium, Artemisia dranunculus, Artemisia santonicum, and Artemisia spicigera essential oils. J Agric Food Chem 53: 9452-9458.

6. Bakkali F., Averbeck S., Averbeck D. \& Idaomar M., 2008. Biological effects of essential oils - a review. Food Chem Toxicol 46 : pp. 446-475.

7. Edris A.E., 2007. Pharmaceutical and therapeutic potentials of essential oils and their individual volatile constituents: A review. Phytother. Res. 21, 308-323.

8. Duarte M.C.T., Figueira G.M., Sartoratto A., Rehder V.L.G., \& Delarmelina C., 2005. - Anticandida activity of Brazilian medicinal plants. Journal of Ethnopharmacology , 97 : 305-311.

9. Tassou C., Drosinos E.H., \& Nychas G.J.E., 1996. Inhibition of resident microbial flora and pathogen inocula on cold fresh fish fillets in olive oil, oregano and lemon juice under modified atmosphere or air. J. Food Prot. 59: pp.31-34.
10. Friedman M., Henika P.R., \& Mandrell R.E., 2002. Bactericidal activities of plant essential oils and some of their isolated constituents against Campylobacter jejuni, Escherichia coli, Listeria monocytogenes, and Salmonella enterica. Journal of Food Protection, Vol. 65, No. 10, pp.1545-1560.

11. Rancic A., Sokovic M., Vukojevic J., Simic A., Mar in P., Duletic-Lausevic S., $\quad$ Djokovic D., 2005. Chemical composition and antimicrobial activities of essential oils of Myrrhis odorata (L.) Scop, Hypericum perforatum L and Helichrysum arenarium (L.): Moench. J Essent Oil Res 17 : 1016.

12. Bernardet J.-F., Segers P., Vancanneyt M., Berthe F., Kersters K., \& Vandamme P., 1996. Cutting a Gordian knot: emended classification and description of the genus Flavobacterium, emended description of the family Flavobacteriaceae, and proposal of Flavobacterium hydatis nom. nov. (basonym, Cytophaga aquatilis Strohl and Tait 1978) Int. J. Syst. Bacteriol. 46 128-148.

13. Austin B., and D. A. Austin., 1999. Bacterial Fish Pathogens: Disease of Farmed and Wild Fish, 3rd (revised) ed Praxis Publishing Chichester, UK.

14. Chahboun N., Esmail A., Abed H., Barrahi M., Amiyare R., Berrabeh M., Oudda H., \& Ouhssine M., 2015. Evaluation de l'activité bactériostatique d'huile essentielle de la Lavandula Officinalis vis-àvis des souches d'origine clinique résistantes aux antibiotiques (Evaluation of the bacteriostatic activity of the essential oil of Lavandula Officinalis towards of the original strains resistant to antibiotics clinic). J. Mater. Environ. Sci. 6 (4) (2015) 11861191; ISSN : 2028-2508.

15. Lamendin H., Toscano G., \& Requirand P., 2004. Phytothérapie et aromathérapie buccodentaires. EMC-Dentisterie, 1(2), 179-192.

16. Haddad P.S., Depot M., Settaf A., Chabli A., \& Cherrah Y., 2003. - Comparative study on the medicinal plants most recommended by traditional practitioners in Morocco and Canada. - J.Herbs, Spices Med. Plants, 10(3), 25-45.

17. Ghedira K., Goetz P., \& Le Jeune R., 2010. Phytothérapie Syzygium aromaticum (L.) Merr. \& Perry (Myrtaceae) Giroflier $\quad 8: \quad 37$. doi:10.1007/s10298-009-0521-5.

18. Demarne F.E., 1985. « Le géranium rosat ». Parfums, Cosmétiques et Arômes, $\mathrm{n}^{\circ} 62$.

19. Soundouss C., 1998. «Les essences de Géranium : Influences pédoclimatique et saisonnière sur les essences Marocaines : Classification par les méthodes d'analyse de données ». Thèse de doctorat en Sciences, Université Aix en Provence, Marseille, 3p. (no: 98 AIX3 0076).

20. Bekkara F.A., Bousmaha L., Bendiab S.T., Boti J. B., \& Casanova J., 2007. Composition chimique de l'huile essentielle de Rosmarinus officinalis L poussant à l'état spontané et cultivé de la région de Tlemcen. 
21. Juergens U.R., Dethlefsen U., \& Steinkamp G., 2003. Anti-inflammatory activity of 1.8-cineol (eucalyptol) in bronchial asthma: a double-blind placebo-controlled trial. Respir Med 97(3): 250256.

22. Sefidkon F.K., Abbasi Z., Jamzad S., Ahmadi F., 2007. "The effect of distillation methods and stage of plant growth on the essential oil content and composition of Satureja rechingeri Jamzad, Food Chemistry, vol.100, pp. 1054-1058.

23. Satrani B., Ghanmi M., Farah A., Aafi A., Fougrach H., Bourkhiss B., Bousta D., \& Talbi M., 2007. Composition chimique et activité antimicrobienne de l'huile essentielle de Cladanthus mixtus. Bull. Soc. Pharm. Bordeaux, 146, pp. 85-96.

24. Rota M.C., Herrera A., Martinez R.M., Sotomayor J.A., \& Jordan M.J., 2008. Antimicrobial activity and chemical composition of Thymus vulgaris, Thymus zygis and Thymus hyemalis essential oils. Food Control 19: 681-687.

25. Kritihi A., Ouaissa K., Oumessoud Y., Maychal A., Barakate M., \& Hasnaoui M. 2017. Characterization of a pathogenic bacteria isolated from rainbow trout fries in a hatchery in Azrou city (Morocco): phenotypic and biochemical studies. J. Wat. Env. Sci. Vol. 1. 140-142.

26. Garnero J., 1996. Phytothérapie-aromathérapie. Encycl. Méd. Nat, p : 20.

27. Pellecuer J., Roussel J.L., \& Andary C., 1973. Propriétés antifongiques comparatives des essences de trois Labiées méditerranéennes : romarin, sarriette et thym. Travaux de la Société de pharmacie de Montpellier 3: 584.

28. Belaiche P., 1979. Traité de phytothérapie et d'aromathérapie. Maloine, tome 1, d'après http://fr.wikipedia.org/wiki/Aromatogramme.

29. Atailia I., and Djahoudi A. 2015. Composition chimique et activité antibactérienne de l'huile essentielle de géranium rosat (Pelargonium graveolens L'Hér.) cultivé en Algérie. Phytothérapie 13, 156-162. https://doi.org/10.1007/s10298-0150950-2.

30. Pintore G., Usai M., \& Bradesi P., 2002. Chemical composition and antimicrobial activity of Rosmarinus officinalis L. oils from Sardinia and Corsica. Flavour and Fragrance Journal 17: 15-19. 